\title{
COMBLIN, José. O Espírito Santo e a tradição de Jesus. São Paulo: Nhanduti, 2012.
}

Marcelo Barros *

Em março de 2011, ao partir dessa vida, de modo repentino e inesperado, o padre José Comblin deixou uma série de escritos que, por desejar revê-los e cada vez atualizá-los, ele ainda não os havia publicado. Eram reflexões teológicas que fundamentavam suas posições críticas com relação ao Vaticano. Tinham como assunto a tensão permanente na história das Igrejas cristãs entre evangelho ou carisma, de um lado e a instituição eclesiástica, do outro. Esse livro que, poucos dias antes de falecer, ele havia me escrito que estava pronto publicar, um ano depois, foi finalmente organizado por Mônica Muggle, secretária e herdeira dos papéis de Comblin e editado pela Ed. Nhanduti, São Paulo.

O texto é uma coletânea de escritos de diferentes momentos, todos elaborados a partir de 2009 e no desejo de responder ao desafio de como se relacionam a novidade e a liberdade do evangelho de Jesus (anúncio do reino) e a organização da Igreja., especialmente da Igreja Romana. A primeira versão, datada de 1 de abril de 2009, era intitulada "A nova descoberta do Evangelho - Introdução à Teologia Contemporânea”. Ali o padre Comblin tenta mostrar que a Igreja necessita de uma nova teologia. A segunda redação do mesmo escrito, de dezembro

\footnotetext{
Resenha publicada no Mutirão (Minga) Temático de Revistas Latino-americanas, organizado pela Comissão Teológica Latino-americana da ASETT/EATWOT (Associação Ecumênica de Teólogos/as do Terceiro Mundo), para 2013.

* Marcelo Barros é monje beneditino e biblista; assessor das CEBs d dos movimentos populares no Brasil É autor de inúmeros livros. País de origem: Brasil. E-mail: horizonte.pucminas@gmail.com.
} 
do mesmo ano, tem um novo título: “O Espírito Santo na Igreja”. Ele o justifica ao escrever: "Chegou a hora de apresentar o Espírito na Igreja. Tudo o que o Espírito Santo faz na Igreja está dirigido em função de sua ação no mundo, já que a Igreja é serviço ao mundo”. No meio de cursos e encontros, em 2010, ele redigiu uma terceira relação com o mesmo título. Ele continuou dando cursos e conferências e o texto ia se adaptando ao que ele percebia depois de cada encontro teológico, conferência e evento do qual ele participava. Mais tarde, no computador ele perde uma das versões desses seus escritos. Seria a quarta versão - foi realmente perdida. A quinta e última foi desenvolvida entre fevereiro e março de 2011, tendo concluído o texto na véspera de seu falecimento (26/ 03/ 2011). Esta que ficou como versão definitiva recebeu o título: “O Espírito Santo e a tradição de Jesus”.

O estilo é simples e quase oral. O conteúdo, apesar de ser sobre assunto teológico do mais alto nível, é acessível a qualquer pessoa que queira ler. Como se tratam de textos póstumos que o autor não teve condições ou tempo de selecionar ele mesmo, Mônica Muggler, organizadora da edição, não se sentiu com o direito de fazê-lo e simplesmente editou os textos pela ordem que encontrou nos papéis deixados por Comblin. E por isso, o livro contém como que quatro edições ou versões da mesma reflexão, cada uma com alguma característica própria. O livro começa pela versão 5 e tem o título “O Espírito Santo e a tradição de Jesus” com uma introdução sobre o mundo de hoje e a ambiguidade do fenômeno religioso. Logo a seguir a primeira parte é sobre a tradição evangélica. Quando pensamos que viria uma segunda parte, o texto é interrompido e se segue a versão 1: A nova descoberta do Evangelho. Introdução à Teologia Contemporânea. Depois de seis capítulos nos quais esse tema é desenvolvido, o livro traz a versão 2 e a versão 3 do texto “O Espírito Santo na Igreja”. E esta versão terceira (p 277 ss) é a definitiva e mais detalhada sobre o assunto.

Esse ir e voltar pode provocar no leitor uma forte impressão de que o livro é feito de repetições e que valeria a pena ter selecionado melhor os textos ou ter publicado apenas a última versão que foi como que o ponto de chegada da reflexão 
do teólogo (a quinta). Entretanto, sem dúvida alguma, o fato de podermos acompanhar a evolução da reflexão pessoal feita por um mestre como Comblin sobre esse tema tão atual e tão complexo tem um valor que não é só pedagógico ou de conteúdo. Sinaliza que Comblin escreve a partir da realidade e se ele vai aprofundando e de certa forma até radicalizando mais a reflexão é porque, de alguma forma, a conjuntura da Igreja e sua realidade também foi evoluindo nesses últimos anos. O texto deixa claro que essa mudança na estrutura eclesiástica não foi para melhor ou para uma eclesiologia mais aberta ou mais espiritual ou evangélica. Comblin tem desabafos que parecem sem nuances e podem parecer apressados, mas sem dúvida, correspondem ao que ele constatava nos seus contatos com a hierarquia. Nos últimos anos, ele costumava afirmar: "Na Igreja Católica de hoje, pode-se criticar nosso senhor Jesus Cristo ou a Deus, mas ao papa, não!”.

Ao ler esse livro do Comblin não pude deixar de recordar o diário publicado de um teólogo de antes do Concílio Vaticano II. Em 1956, em outro contexto de Igreja, na Inglaterra, o padre Yves Congar, teólogo dominicano francês, escrevia em uma carta à sua mãe: "Não sou de fazer confidências, mas depois dos seis meses de exílio que me impuseram, isso me leva a falar [...] O problema não é o que eu possa ter dito de falso, mesmo aos olhos deles (da cúria romana). É simplesmente que eu tenha dito coisas que eles não gostam que sejam ditas. É que eu toquei em assuntos sem me alinhar no único artigo que as autoridades eclesiásticas de Roma querem impor ao comportamento de toda a cristandade. Este comportamento consiste em não pensar nada e não dizer nada. Há um papa que pensa tudo, diz tudo e ser católico é obedecer a ele. [...] Só se pode dizer: “é genial!”. [...] O papa atual desenvolveu um regime paternalista que consiste no fato de que ele e só ele diz ao mundo e a cada um o que as pessoas devem pensar e o que e como devem fazer. Ele quer reduzir os teólogos a simplesmente comentar seus discursos e principalmente não ter a veleidade de pretender pensar alguma coisa, ou propor nada fora deste comentário.[...] É evidente que Roma nunca procurou e não procura a não ser uma 
coisa: a afirmação de sua autoridade. O resto só interessa enquanto serve como exercício para este poder"1.

Do mesmo modo que a caminhada dos movimentos eclesiais, mesmo perseguidos fecundou um solo fértil que, um dia, depois de muitos sofrimentos e injustiças, depois da morte do papa Pio XII, desabrochou no Concílio Vaticano II, atualmente esse livro do nosso mestre José Comblin nos reacende a esperança de que esses tempos de inverno não sejam definitivos e um dia, uma primavera nova possa florescer para as Igrejas e para o mundo.

${ }^{11}$ CONGAR, Yves. Journal d'um Théologien, 1946- 1956. Paris: Ed. du Cerf, 2005, p. 424. 